\title{
PUSAT-PUSAT PERKEMBANGAN TAREKAT NAQSYABANDIYAH DI TAPANULI BAGIAN SELATAN
}

\author{
Erawadi \\ Fakultas Ilmu Tarbiyah dan Keguruan IAIN Padangsidimpuan \\ Jl. Imam Bonjol KM 4,5 Sihitang, Padangsidimpuan 22733 \\ e-mail: era08_nad@yahoo.co.id
}

\begin{abstract}
Abstrak: Tulisan ini menelusuri perkembangan tarekat Naqsyabandiyah di wilayah Tapanuli Bagian Selatan melalui beberapa pusat tarekat Naqsyabandiyah dengan menggunakan prinsip sejarah lokal. Tarekat ini di kawasan tersebut datang dari dua sumber, yaitu dari Minangkabau, Sumatera Barat, dan Babussalam, Langkat, Sumatera Utara. Pengaruh dari Minangkabau terutama melalui Syaikh Ibrahim Kumpulan, sedangkan dari Babussalam, Langkat melalui Syaikh Abdul Wahab Rokan. Namun demikian, sebagian Syaikh Naqsyabandiyah asal Tapanuli Bagian Selatan, setelah belajar pada Syaikh setempat, pergi dan belajar di Haramain. Sebagian mereka belajar langsung pada Syaikh Sulaiman Zuhdi atau Syaikh Ali Ridha di Jabal Abu Qubaisy. Di antara pusat-pusat perkembangan tarekat Naqsyabandiyah di Tapanuli Bagian Selatan adalah Hutapungkut, Aek Libung, Sayurmatinggi, Nabundong, Sipirok, Pudun, Aek Tuhul, Ujung Padang, dan Batu Gajah. Kebanyakan organisasi tarekat ini telah bertahan selama beberapa generasi, namun sebagiannya tidak bertahan karena faktor-faktor tertentu.
\end{abstract}

\begin{abstract}
The Centres of Tarekat Naqshabandiyah in South Tapanuli Region. Using the principles of local history, this article traces the developments of Thariqat Naqshabandiyah in Southern Tapanuli through its many centers of activities. This thariqat reached the region by ways of Minangkabau West Sumatra and Babussalam Langkat North Sumatra with Syaikh Ibrahim Kumpulan and Syaikh Abdul Wahab Rokan being the central figures. However, some of the region's Naqshabandiyah syaikhs, after learnign under local masters, continue their learning to Haramayn, Hijaz. Mostly, they learn under the celebrated Syaikh Sulayman Zuhdi or Syaikh Ali Ridha at Jabal Abu Qubaysh. The most important Naqshabandiyah center of the region are to be found in Hutapungkut, Kotanopan, Mandailing Natal; Aek Libung, Sayurmatinggi, Nabundong, Sipirok, Tapanuli Selatan; Pudun, Aek Tuhul, Ujung Padang, Padangsidimpuan; and Batu Gajah, Barumun, Padang Lawas. Most of these centers have survived for generations; some, however, have not survived for different reasons.
\end{abstract}

Kata Kunci: tarekat Naqsyabandiyah, pusat tarekat, Tapanuli Selatan 


\section{Pendahuluan}

Menjelang penghujung abad XIII, ketika tasawuf menjadi corak pemikiran yang dominan di dunia Islam, dan tarekat sedang berada di puncak kejayaannya, proses islamisasi di Indonesia mulai menampakkan hasilnya secara budaya dan politik. ${ }^{1}$ Dalam proses islamisasi tersebut peranan para sufi sangat besar. Jika sebelumnya, ketika dilakukan oleh para pendakwah dan pedagang, islamisasi belum bisa menembus entitas politik dan kekuasaan, islamisasi hanya berkisar pada islamisasi masyarakat dan budaya saja. Namun, ketika proses itu melibatkan sejumlah para sufi dengan pendekatan sufistik (mistik), mereka mampu mengislamkan para raja di Indonesia, kemudian diikuti oleh rakyatnya.

Proses ini kemudian dilanjutkan oleh para ulama Nusantara yang belajar di pusatpusat peradaban Islam, khususnya di Makkah, Madinah, dan Mesir. Mereka masuk dalam jaringan ulama Dunia Islam, yang peran sebagian mereka tidak hanya di Indonesia, tetapi juga di wilayah lainnya. Para ulama Nusantara di Haramayn, setelah menuntut ilmu beberapa waktu sebagian mereka kembali ke tanah air, namun tidak sedikit pula yang bermukim di Haramayn. ${ }^{2}$

Pengabdian dan perjuangan mereka diwujudkan dengan membentuk berbagai lembaga keagamaan, sebagai wadah dan sarana pembinaan dan praktik keagamaan. Kemudian muncul pusat-pusat pendidikan dan praktik-praktik keagamaan, seperti madrasah, pesantren, tarekat dan persulukan, yang sampai sekarang sebagiannya masih tetap eksis dalam masyarakat. Dalam pembahasan ini, akan dibatasi kajian hanya pada pusat-pusat perkembangan tarekat Naqsyabandiyah di Tapanuli Bagian Selatan ${ }^{3}$ dalam konteks sejarah lokal (local history) dengan pendekatan historis sosiologis.

\section{Islamisasi dan Tarekat Naqsyabandiyah}

Sebelum kedatangan Islam di Tapanuli Bagian Selatan, para dukun pemanggil roh, yang disebut parsibaso dan datu, mempunyai peranan penting dalam masyarakat dan pemerintahan. Mereka menjalankan fungsi sangat penting dalam masyarakat Batak

${ }^{1}$ Martin van Bruinessen, Tarekat Naqsyabandiyah di Indonesia, Cet. 4 (Bandung: Mizan, 1996), h. 15.

${ }^{2}$ Azyumardi Azra, Renaisans Islam Asia Tenggara: Sejarah Wacana \& Kekuasaan (Jakarta: Remaja Rosdakarya, 2006), h. 150.

${ }^{3}$ Wilayah Tapanuli pada masa kolonialisme Belanda, secara geografis dan administratif, dibagi menjadi dua wilayah, yaitu Tapanuli Utara dan Tapanuli Selatan. Kemudian pada masa kemerdekaan, Tapanuli Selatan dimekarkan menjadi Kabupaten Tapanuli Selatan (1956), Kabupaten Mandailing Natal (1998), Kota Padangsidimpuan (2001), Kabupaten Padang Lawas (2007), dan Padang Lawas Utara (2007). Sementara Tapanuli Utara dimekarkan menjadi Kabupaten Tapanuli Utara (1956), Kota Sibolga (1956), Tapanuli Tengah (1956), Kabupaten Simalungun (1956), Kabupaten Toba Samosir (1998), Kabupaten Humbang Hasundutan (2003), dan Kabupaten Samosir (2003). Pembahasan ini hanya menelusuri obyek kajian di wilayah pemekaran Tapanuli Selatan, yang sekarang sering disebut Tapanuli Bagian Selatan. 
dan menjadi bagian dari elit yang memerintah. Oleh karena itu, perpindahan ke agama Islam secara sempurna, hanyalah mungkin bila ada orang pintar di kalangan Muslim yang mampu mengambil alih peran-peran yang dimainkan oleh para parsibaso dan datu dalam berhubungan dengan alam gaib dan penyembuhan berbagai penyakit psikosomatik. Dalam hal ini, guru-guru (para mursyid dan khalifah) tarekat, agaknya, merupakan caloncalon kuat untuk menggantikan para parsibaso dan datu tersebut. Kenyataannya, mayoritas ulama yang di kemudian hari bertindak sebagai datu adalah guru-guru atau pengikut tarekat Naqsyabandiyah. ${ }^{4}$

Penyebaran tarekat Naqsyabandiyah di Tapanuli Selatan hampir langsung mengikuti para juru dakwah Islam pertama. Sebelum kedatangan kaum Paderi ke wilayah Mandailing, beberapa kepala adat Batak Mandailing telah menganut agama Islam. Islamisasi selanjutnya dilakukan melalui gerakan Padri, yang awalnya mengadakan pembaharuan dan pemurnian kehidupan serta pemahaman beragama (Islam) di daerah Minangkabau. Perluasan pengaruh dan kekuasaan Paderi dalam menyiarkan Islam di bagian Selatan Tapanuli dilakukan mulai tahun 1816 M, ketika pasukan Tuanku Tambusai, yaitu grup tentara Bonjol yang bergerak dari Sungai Rokan memasuki daerah Tapanuli Selatan. ${ }^{5}$

Dengan demikian, proses penyebaran Islam di wilayah Tapanuli Bagian Selatan, secara umum, dapat dibagi ke dalam 3 (tiga) periode, yaitu: Pertama, periode pra Paderi. Penyebaran Islam, pada periode ini dilakukan oleh para juru dakwah dan guru/pengikut tarekat, khususnya tarekat Naqsyabandiyah, dengan pendekatan damai dan sufistik. Kedua, periode masa Paderi (1816-1838). Penyebaran Islam dilakukan oleh kaum Paderi dengan pendekatan fikih (syariat) dan perang. Ketiga, periode pasca Paderi (1838-sekarang). Penyebaran kembali dilakukan oleh para juru dakwah dan guru/pengikut tarekat, kemudian diikuti dengan organisasi sosial keagamaan tertentu.

Pada paruh pertama periode ketiga inilah terjadinya puncak perkembangan tarekat Naqsyabandiyah di wilayah Tapanuli Bagian Selatan, yaitu pada akhir abad XIX dan awal abad XX (pergantian abad). Pada periode ini tarekat Naqsyabandiyah, khususnya di wilayah Mandailing, telah berakar sedemikian kuatnya. Amalan-amalan tarekat ini, tampaknya, hampir dianggap bagian tidak terpisahkan dari Islam. Suluk, meskipun diamalkan oleh sejumlah orang saja, dianggap sebagai tingkatan tertinggi dalam pelajaran keislaman.

Pengaruh tarekat Naqsyabandiyah di Tapanuli Bagian Selatan datang dari dua sumber, yaitu dari Minangkabau, ${ }^{6}$ khususnya melalui Syaikh Ibrahim Kumpulan; dan dari

${ }^{4}$ Martin van Bruinessen, Tarekat Naqsyabandiyah, h. 141-142.

5Ibid., h. 141; Taufik Abdullah, Sejarah Lokal di Indonesia (Yogyakarta: Gajah Mada University Press, 1979), h. 223; M. O. Parlindungan, Tuanku Rao (Jakarta: Tanjung Pengharapan, 1964), h. $165-171$.

${ }^{6}$ Perkembangan tarekat Naqsyabandiyah di Minangkabau mendapat pengaruh yang sangat kuat dari Timur Tengah, bahkan sampai awal abad XX. Hal ini disebabkan oleh jalur geneologis ulama tarekat yang berporos pada ulama yang bermukim atau pernah mengajar di Haramayn 
Babussalam, Langkat: Syaikh Abdul Wahab Rokan, khususnya melalui khalifahnya Syaikh Sulaiman al-Kholidy, ${ }^{7}$ dan Syaikh Abdul Manan. Meskipun demikian, sebagian syaikh Naqsyabandiyah asal Tapanuli Bagian Selatan, setelah belajar pada syaikh setempat, pergi ke Makkah, dan belajar langsung pada Syaikh Sulaiman Zuhdi atau Ali Ridha di Jabal Abu Qubaisy, atau ulama lainnya. Mereka itu antara lain Syaikh Muhammad Bashir al-Khalidi Naqsyabandi, Syaikh Syihabuddin Aek Libung, Syaikh Sulaiman Aek Libung, Syaikh Muhammad Thoib (Baleo Batu Gajah), Syaikh Zainal Abidin Pudun Julu, dan Syaikh Ahmad Daud (Tuan Nabundong). Di samping syaikh Naqsyabandi yang disebut di atas, tentu juga terdapat syaikh-syaikh lainnya, baik yang belajar di tanah air, maupun belajar ke Makkah dan Mesir.

\section{Pusat-Pusat Perkembangan Tarekat Naqsyabandiyah}

Tarekat Naqsyabandiyah berkembang di beberapa tempat di wilayah Tapanuli Bagian Selatan melalui para khalifahnya. Prosesi pergantian kepemimpinan dalam tarekat sama dengan prosesi pergantian kepemimpinan dalam sistem pemerintahan monarkhi (kerajaan), meskipun proses persiapan penggantinya tidak persis sama. Biasanya jabatan tertinggi dalam sebuah organisasi tarekat, diturunkan kepada khalifah yang juga anak, cucu, saudara, atau keluarga terdekat yang dianggap layak dan mampu memimpin tarekat dan persulukan. Bedanya dengan sistem pemerintahan monarkhi, dalam tarekat untuk menjadi seorang khalifah atau untuk membuka persulukan baru harus mendapat ijazah tarekat dan izin dari guru dan khalifah lainnya. Proses pergantian tersebut terjadi dengan kepemimpinan organisasi tarekat di berbagai tempat, sehingga tarekat tertentu terpusat terus-menerus di suatu tempat hingga beberapa generasi, namun sebagiannya tidak bertahan karena faktor-faktor tertentu, baik faktor internal, maupun faktor eksternal. Adapun pusat-pusat organisasi tarekat, khususnya tarekat Naqsyabandiyah, di wilayah Tapanuli Bagian Selatan, di antaranya adalah Hutapungkut, Kota Nopan, Mandailing Natal; Aek Libung, Sayurmatinggi, Tapanuli Selatan; Nabundong, Sipirok, Tapanuli Selatan; Pudun, Padangsidimpuan Batunadua, Padangsidimpuan; Aek Tuhul, Padangsidimpuan Selatan, Padangsidimpuan; Ujung Padang, Padangsidimpuan Timur, Padangsidimpuan; dan Batu Gajah, Barumun, Padang Lawas.

\section{Hutapungkut, Kotanopan, Mandailing Natal}

Penyebaran tarekat Naqsyabandiyah di Mandailing Natal, di antaranya, dikembangkan

dan pembacaan yang intens terhadap kitab-kitab tertentu yang pernah berkembang di Haramayn Lihat Arrazy Hasyim, "al-Tariqah al-Naqsyabandiyah fi Minangkabau: Tarjmat Kitab al-Sa'adah al-Abadiyah li Shaykh 'Abd al-Qadim", dalam Studia Islamika, Volume 18, Nomor 1, 2011, h. 103-104.

${ }^{7}$ Martin van Bruinessen, Tarekat Naqsyabandiyah, h. 141-142. 
oleh Syaikh Sulaiman al-Khalidi Hutapungkut (1841-1917). Ia merupakan salah seorang khalifah Abdul Wahab Rokan, sebagaimana disebutkan Fuad Said (cucu Abdul Wahab Rokan), yang berasal dari Tapanuli Selatan. ${ }^{8}$ Ayahnya, Japagar, seorang jago silat kenamaan. Sejak kecil, ia sudah diajarkan silat oleh ayahnya, sehingga ia pun terkenal sebagai jagoan silat. ${ }^{9}$

Awalnya, ia belajar tarekat dan suluk pada Syaikh Abdul Wahab Rokan selama lebih kurang 5 (lima) tahun, 1862-1868, kemudian ia pergi ke Makkah, dan bermukim di sana selama 4 (empat) tahun untuk belajar lebih lanjut pada Syaikh Sulaiman Zuhdi di Jabal Qubaisy. Setelah kembali ke Sumatera, ia tinggal bersama guru pertamanya, Syaikh Abdul Wahab Rokan, di Babussalam. Kemudian ia kembali ke kampungnya, Hutapungkut, Kota Nopan, Mandailing Natal. Ia membangun sebuah masjid dan mendirikan persulukan di Hutapungkut. Murid-muridnya berasal dari berbagai daerah, seperti Muara Sipongi, Pekatan, Ranjau Batu, dan Padang Lawas.

Di antara murid-muridnya yang terpenting adalah Syaikh Hasyim dari Ranjau Batu, Syaikh Abdul Majid dari Tanjung Larang (Muara Sipongi), Syaikh Ismail dari Muara Sipongi, Syaikh Muhammad Samman dari Kampung Sejaring (Bukit Tinggi), dan Syaikh Muhammad Baqi (putra dan penggantinya). ${ }^{10}$

Syaikh Hasyim dari Ranjau Batu, yang terkenal juga dengan Syaikh Muhammad Hasyim al-Khalidi, kemudian, belajar pada Syaikh Ali Ridha di Jabal Qubis Makkah, dan menerima ijazah tarekat Naqsyabandiyah darinya. Setelah kembali ke tanah air, ia menetap dan membuka persulukan di Buayan, Bukit Tinggi, Sumatera Barat. Syaikh Kadirun Yahya al-Khalidi belajar dan menerima ijazah tarekat Naqsyabandiyah Mujaddiyah Khalidiyah dari Syaikh Muhammad Hasyim al-Khalidi ini. ${ }^{11}$

Meskipun respon penerimaan terhadap keberadaan tarekat di Hutapungkut ini sangat luas, namun terdapat juga orang-orang yang mengkritisi, bahkan menolaknya. Fenomena ini, sesungguhnya, fenomena yang terjadi hampir di seluruh wilayah Islam pada periode modern. Secara umum, munculnya gerakan pembaharuan dalam berbagai bidang, dianggap sebagai respon terhadap kondisi, pemahaman, dan praktik keagamaan masyarakat masa itu.

Seorang ulama Mandailing, Syaikh Abdul Hamid, misalnya, yang kembali dari Makkah

${ }^{8}$ A. Fuad Said, Syeikh Abdul Wahab Tuan Guru Babussalam (Medan: Pustaka Babussalam, 1983), h. 135.

${ }^{9}$ Harun Nasution, et.al., Ensiklopedi Islam Indonesia (Jakarta: Djambatan, 1992), h. 872.

${ }^{10}$ Martin van Bruinessen, Tarekat Naqsyabandiyah, h. 142; Lihat juga Usman Pelly, "Ulama di Mandailing, sebagai Bahan Perbandingan untuk Kasus Kaji: Ulama di Tiga Kerajaan Melayu Pesisir", dalam Bulletin Proyek Penelitian Agama dan Perubahan Sosial (LEKNAS-LIPI), No. 6, h. 1-35; Harun Nasution et.al., Ensiklopedi Islam, h. 872.

${ }^{11}$ Djamaan Nur, Tasawuf dan Tarekat Naqsyabandiyah Pimpinan Prof. Dr. H. Saidi Syeikh Kadirun Yahya, Cet. 2 (Medan: USU Press, 2002), h. 185-186. 
tahun 1895, setelah belajar pada Ahmad Khatib al-Minangkabawi sekitar 10 (sepuluh) tahun dan menetap di Hutapungkut. Ia mengikuti contoh yang diberikan gurunya, dan cukup terkenal sebagai penentang tarekat dan juga adat. Meskipun demikian, hubungannya dengan Syaikh Sulaiman al-Khalidi, sebagai syaikh utama tarekat Naqsyabandi, tetap bersahabat, namun hubungannya dengan para pengetua adat sangat kurang serasi.

Dia diajukan ke muka pengadilan dan selama beberapa tahun (1918-1920) mendapat tekanan untuk tinggal di luar Mandailing. Walaupun dalam kondisi demikian, berkat usahausahanya Serikat Islam dan Permi, yang modernis, mendapat pijakan di Mandailing, namun kaum pembaharu ini tetap merupakan minoritas di wilayah ini.

\section{Aek Libung, Sayurmatinggi, Tapanuli Selatan}

Tarekat Naqsyabandiyah di Aek Libung Sayurmatinggi Tapanuli Selatan ${ }^{12}$ dikembangkan oleh Syaikh Syihabuddin Aek Libung, bermarga Nasution (1892-1967). Ia termasuk salah seorang murid Syaikh Muhammad Ali Ridha di Jabal Abu Qubaisy, Makkah. Nama lengkapnya adalah Syaikh Syihabuddin bin Syaikh Rowany al-Khalidy Naqsyabandy bin Mangindal bin Maharaja Manambir Mandailing.

Pada pendahuluan kitab Âdâb al-Muridîn, karangan Syihabuddin, disebutkan silsilah keturunannya, yaitu: “... Faqir yang berkehendak kepada Allah Ta'ala, yaitu Syaikh Syihab al-Din anak al-Marhum Malim pada Syaikh Khalifah Rowani al-Khalidi Naqshabandi anak Mangindal anak Maharaja Manambir Mandahiling ...". ${ }^{13}$ Lalu pada halaman penutup ia menyebutkan: “... hamba al-Faqir Syaikh Syihabuddin di Kampung Sane-Sane, Sayurmatinggi, anak al-Marhum Malim pada Tuan Khalifah Rowani al-Khalidi Naqsyabandi di Muara Langkumas Sulang Aling anak Mangindal anak Maharaja Manambir (marga Nasution) di Kampung Sirangkap Gunung Beringin, Mandahiling Godang". ${ }^{4}$

Hal yang sama juga disebutkannya pada halaman penutup kitab Fath al-Qalb: “... hamba yang faqir yang sangat berharap kepada Allah Ta'ala, yaitu Syaikh Syihabuddin di Kampung Sane-Sane, Dewan Nagari Sayurmatinggi anak'alim pada Syaikh Khalifah Rowani al-Khalidi Naqsyabandi Muara Langkumas Sulang Aling anak Mangindal anak Maharaja Manambir (marga Nasution) di Kampung Sirangkap Gunung Beringin, Mandahiling Godang...". 15

Data historis ini mengandung beberapa informasi penting dalam konteks sejarah lokal (local history), khususnya sejarah Islam di wilayah Tapanuli Bagian Selatan. Ia tidak hanya menginformasikan silsilah nasab (keturunan)-nya, tetapi juga tempat-tempat,

\footnotetext{
${ }^{12}$ Secara administrasi negara, wilayah ini sekarang masuk ke dalam Kabupaten Tapanuli Selatan, tetapi secara budaya masyarakatnya adalah orang-orang Mandailing

${ }^{13}$ Syihabuddin, Âdâb al-Muridîn (Medan: Pertjatimoer, t.t.), h. 1.

${ }^{14}$ Ibid., h. 63-64.

${ }^{15}$ Syihabuddin, Fath al-Qalb (t.t.p.: t.p., t.t.), h. 70.
} 
kedudukan, ajaran/aliran agama yang diikuti orang-orang tertentu yang merupakan silsilah keturunannya.

Data tersebut menginformasikan beberapa tempat yang mungkin menjadi tempat asal, tempat tinggal atau tempat kiprah perjuangan dan pengabdiannya. Nama-nama tempat yang disebutkan adalah Kampung Sane-Sane, Nagari Sayurmatinggi, Muara Langkumas, Sulang Aling, Kampung Sirangkap, Gunung Baringin, dan Mandailing (Mandahiling) Godang. Penyebutan tempat Kampung Sane-Sane, Nagari Sayurmatinggi dilekatkan pada nama Syihabuddin, penyebutan tempat Muara Langkumas, Sulang Aling dilekatkan pada ayahnya, Rowani, sedangkan penyebutan tempat Kampung Sirangkap, Gunung Baringin, Mandailing Godang, dilekatkan pada kakek buyutnya, Manambir.

Penyebutan tempat atau penisbahan tempat kepada seseorang merupakan sebuah tradisi Islam yang telah berlangsung lama. Nama-nama tempat, bahkan kadang-kadang nama profesi, aliran/paham/mazhab keagamaan, atau sifat tertentu, menjadi kebiasaan yang turun temurun, yang dilekatkan pada ulama atau orang-orang tertentu.

Penyebutan nama tempat, misalnya al-Makki (Makkah), al-Bagdâdî (Bagdad), alMadani (Madinah), al-Mishrî (Mesir), al-Syâmî (Syam/Syiria), al-Bukhârî (Bukhara), al-Hindî (India), al-Kurdî (Kurdistan), al-Rûmî (Rum/Turki), dan sebagainya. Penyebutan nama profesi, seperti al-Qushâshî (penjual barang-barang bekas), dan sebagainya. Penyebutan nama aliran/paham keagamaan, seperti al-Naqsyabandi (salah satu nama tarekat), al-Khalidi, al-Khalwatî (keduanya, nama cabang tarekat Naqsyabandi), al-Syafiî (mazhab fikih yang berasal dari Imam al-Syafiı̂̀, al-Asy`arî (aliran/paham teologi yang berasal dari Imam al-Asy'arî), dan sebagainya. Penyebutan sifat tertentu, misalnya al-Shiddiq (benar, gelar yang diberikan kepada Abû Bakar), al-Faruq (pembeda, 'Umar bin Khaththâb), dan sebagainya. Penyebutannya, kadang-kadang, tanpa diikuti nama orangnya, tetapi langsung nama kedudukan/jabatan dan nama tempat, seperti Teungku Chik di Tiro, Imam Bonjol, dan Tuan Syeikh Ulakan.

Di Indonesia penyebutan tersebut, misalnya al-Fansuri (Fanshur, Barus) yang dilekatkan pada nama Hamzah al-Fanshuri, Abdurrauf al-Fanshuri al-Singkili; al-Sumatrani (Sumatera) dilekatkan pada Syamsuddin al-Sumatrani; al-Raniri (Ranir, India) dilekatkan pada Nuruddin al-Raniri; Rokan (Riau) dilekatkan pada Abdul Wahab Rokan; al-Mingkabawi (Minangkabau) dilekatkan, misalnya, pada Ismail al-Khalidi al-Minangkabawi dan Ahmad Khatib al-Minangkabawi; Ulakan (nama tempat di Sumatera Barat) dilekatkan pada Burhanuddin Ulakan, al-Palimbani (Palembang) dilekatkan pada Abdussamad al-Palimbani; al-Makassari (Makassar, Sulawesi) diberikan kepada Muhammad Yusuf al-Makassari; al-Banjari (Banjar, Kalimantan) dilekatkan pada Muhammad Arsyad al-Banjari, Muhammad Nafis al-Banjari; al-Bugisi (Bugis, Sulawesi) pada Abdul Wahab al-Bugisi (Sulawesi), alBatawi (Batavia, Jakarta) pada Abdurrahman al-Masri al-Batawi; dan sebagainya.

Dalam konteks tradisi lokal di Tapanuli Bagian Selatan penyebutannya juga seperti itu, misalnya nama tempat al-Mandili (Mandailing) dilekatkan, misalnya, pada Abdul Jalil 
al-Mandili dan Abdul Qadir al-Mandili; Hutapungkut (Kota Nopan, Mandailing Natal) dilekatkan pada Sulaiman al-Khalidi Hutapungkut; Padang Lawas dilekatkan pada Abu Bakar Padang Lawas; Gunung Berani pada Haji Yusuf Gunung Berani; Panyabungan (Mandailing Natal) dilekatkan, misalnya, pada Muhammad Ya'qub Panyabungan dan Muhammad Ja'far Panyabungan; Muara Mais (Angkola) pada Abdul Wahab Muara Mais; Nabundong (Sosopan) pada Ahmad Daud Nabundong; dan sebagainya. Penyebutan yang tanpa diikuti nama orangnya, tetapi langsung nama kedudukan/jabatan dan nama tempat, seperti Tuan Nabundong, Balelo Batu Gajah, dan Tuan Syeikh Aek Libung.

Dengan demikian, penyebutan tempat Kampung Sane-Sane, Nagari Sayurmatinggi dilekatkan pada nama Syihabuddin, menunjukkan bahwa pusat pengabdian dan pengembangan agama/ajaran yang diyakininya di Kampung Sane-Sane (sekarang disebut Aek Libung), Kecamatan Sayurmatinggi, Kabupaten Tapanuli Selatan.

Bukti arkeologi yang menguatkan hal tersebut, berupa situs/artefak Masjid dan makam, dapat ditemui di Aek Libung. Namun masjid yang dibangun dari kayu oleh Syaikh Syihabuddin tahun 1919 direnovasi secara menyeluruh, yang pengerjaannya mulai dilakukan awal bulan Desember 2013 (penulis sangat beruntung karena hadir pada saat pembacaan doa di mesjid tersebut dalam rangka memulai renovasi). Di dinding depan masjid Syaikh Syihabuddin terdapat dekorasi kaligrafi kalimat syahadah dan tawajjuh, serta gantungan beberapa bingkai tawajjuh dan kutipan hadis oleh Syaikh Husein bin Syihabuddin.

Selanjutnya, penyebutan tempat Muara Langkumas, Sulang Aling dilekatkan pada ayahnya, Rowani, menunjukkan bahwa Rowani, ayah dari Syihabuddin, mengembangkan dakwah dan ajaran tarekatnya di Muara Langkumas, Sulang Aling, Kecamatan Muara Batang Gadis, Kabupaten Mandailing Natal.

Demikian juga dengan penyebutan tempat Kampung Sirangkap, Gunung Baringin, Mandailing Godang, dilekatkan pada kakek buyutnya, Manambir, menegaskan bahwa Manambir hidup dan mengabdi di Sirangkap (Gunung Baringin), Kecamatan Panyabungan Timur, Kabupaten Mandailing Natal, Propinsi Sumatera Utara. Menyangkut dengan asal-usul keturunan ini belum dapat dipastikan, dan karenanya memerlukan penelusuran lebih lanjut. Mungkin saja mereka, berdasarkan penyebutan nama tempat "Maharaja Manambir (marga Nasution) di Kampung Sirangkap Gunung Beringin, Mandahiling Godang"16 adalah penduduk asli, sehingga menjadi golongan penguasa/bangsawan (maharaja). Pendapat (teori) lain menyebutkan bahwa keturunan Syaikh Syihabuddin berasal dari Sigorbus, Sibuhuan, kemudian pindah ke Matondang, ${ }^{17}$ tetapi teori ini tidak menjelaskan waktu dan proses perpindahan lebih lanjut, sehingga sampai ke Sirangkap, Panyabungan Timur, Mandailing Natal.

${ }^{16}$ Syihabuddin, Âdâb al-Muridîn, h. 64.

${ }^{17}$ Anwar Saleh Daulay, et.al. "Sejarah Ulama Ulama Terkemuka Tapanuli Selatan," Penelitian (Fakultas Tarbiyah IAIN Sumatera Utara, Padangsidimpuan, 1987), h. 48. 
Berdasarkan data historis tersebut di atas, terdapat juga beberapa penyebutan gelar/ laqab yang menunjukkan kedudukan atau ajaran/aliran keagamaan yang dianutnya, yaitu al-faqir, syaikh, malim, al-'alim al-'allamah, khalifah, al-khalidi, Naqsyabandi, dan maharaja. Gelar al-faqir disebutkan mengikuti nama Syihabuddin; syaikh mengikuti nama Sulaiman, Syihabuddin, dan Rowani (masing-masing anak, ayah, dan kakek); al-'alim al-'allamah hanya mengikuti nama Syihabuddin; malim, khalifah, al-khalidi, dan Naqsyabandi mengikuti nama Rowani; sedangkan maharaja mengikuti nama Manambir.

Gelar al-faqir menunjukkan kerendahan hati seorang penulis. Meskipun ia telah berusaha sekuat tenaga dan mengerahkan semua kemampuan dan ilmunya untuk menulis, namun ia menyadari bahwa ilmu yang ditulisnya itu tidak seberapa dibandingkan dengan ilmu Allah S.W.T. Oleh karena itu, ia, sebagai hamba Allah, merasa seperti seorang fakir di sisi-Nya.

Gelar syaikh, al-Alim, al-Alamah, atau al-Alim al-Alamah diberikan kepada seseorang yang mempunyai ilmu pada tingkat tertentu. Penyebutan dengan gelar al-Alim al-Alamah pada nama Syihabuddin menunjukkan bahwa Syaikh Syihabuddin termasuk salah seorang ulama Nusantara yang diberi gelar al-Alim al-Allamah (semacam guru besar), sebuah gelar kehormatan dalam bidang keilmuan yang hanya dimiliki oleh beberapa ulama Indonesia. Gelar yang sama juga diberikan kepada ulama seperti Nuruddin al-Raniri, Abdurrauf al-Fansuri, Muhammad al-Nawawi al-Bantani, ${ }^{18}$ Yusuf al-Makassari, Abdussamad al-Palimbani, Muhammad Zayn al-Asyi, dan Jalaluddin al-Turusani. Ini juga mengindikasikan bahwa Syaikh Syihabuddin mempunyai ilmu yang setingkat, atau setidak-tidaknya mendekati, dengan para ulama Indonesia lainnya yang mempunyai gelar keilmuan al'Alim al-'Allamah.

Penyebutan gelar syaikh, khalifah, al-Khalidi, dan Naqsyabandi pada Rowani, orangtua dari Syihabuddin menunjukkan bahwa ia merupakan seorang khalifah tarekat Naqsyabandiyah cabang Khalidiyah. Penulis belum mendapatkan data dan informasi yang memuaskan tentang biografi, pemikiran, perjuangan, dan peranan Rowani dalam proses penyebaran dan pengembangan Islam di wilayah Mandailing, atau mungkin di wilayah lain. Demikian juga dengan penyebutan maharaja bagi Manambir, kakek buyut Syihabuddin. Ini menyatakan bahwa Manambir seorang bangsawan Mandailing pada masanya. Kebangsawanan ini, biasanya, terus melekat pada keturunannya.

Data tersebut juga mengkonfirmasikan bahwa terdapat satu silsilah keturunan, yaitu Syihabuddin adalah putra Rowani, Rowani adalah putra Mangindal, dan Mangindal

${ }^{18}$ Muhammad al-Nawawi al-Bantani lahir di Tanara, Banten, Jawa Barat (sekarang Propinsi Banten) tahun 1813, dan wafat 1897 M. Al-Nawawi menetap di Mekkah sejak tahun 1855, dan menjadi salah seorang ulama Jawi yang paling terkenal di Haramayn. Ia menghasilkan 26 karya, dan yang paling terkenal adalah Tafsir Nur Marah Labib. Lihat Azyumardi Azra, Jaringan Ulama Timur Tengah dan Kepulauan Nusantara Abad XVII dan XVIII: Akar Pembaruan Islam Indonesia (Jakarta: Kencana, 2004), h. 379. 
adalah putra Manambir yang bermarga Nasution, sehingga silsilah lengkapnya Sulaiman bin Syihabuddin bin Rowani bin Mangindal bin Manambir Nasution.

Selanjutnya silsilah anak dan cucunya mengikuti silsilah tersebut, sebagaimana

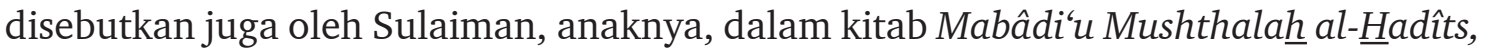
bahwa: "Syaikh Sulaiman bin al-Alim al-'Allamah Syaikh Syihabuddin al-Indunisiya" dan pada halaman akhir penyebutannya lebih lengkap, yaitu "Syaikh Sulaiman bin al-Alim al-'Allamah Syaikh Syihabuddin bin al-Marhum al-Syaikh Rowani al-Khalidi Naqsyabandi bin Mangindal bin Maharaja Manambir Mandahiling". ${ }^{19}$

Demikian juga anak atau cucunya yang lain, misalnya Mulkan bin Husein bin Syihabuddin bin Rowani bin Mangindal bin Manambir Nasution. Silsilah keturunan ini, tentu, berbeda dengan silsilah tarekat yang dianut oleh mereka, karena anak belum tentu menerima ijazah tarekat dari ayahnya.

Praktik tarekat dan persulukan, serta pengembangannya di Aek Libung, Sayurmatinggi, Tapanuli Selatan, setelah meninggalnya Syaikh Syihabuddin tahun 1967M, dilanjutkan oleh Syaikh Sulaiman (anaknya), dan kemudian Syaikh Husein (anaknya), dan Syaikh Mulkan bin Husein (cucunya, sampai sekarang).

Syaikh Sulaiman lahir di Aek Libung, Batang Angkola, Tapanuli Selatan tahun 1905 dan wafat tahun 1970 di Aek Libung Sayurmatinggi. ${ }^{20}$ Ia awalnya belajar di Madrasah Mushthafawiyah Purbabaru, kemudian pergi ke Makkah belajar selama 15 (lima belas) tahun, di antaranya belajar di Madrasah Dar al-'Ulum al-Diniyah. Di antara gurunya di Makkah adalah Syaikh Abdul Qadir Mandily. Ia juga belajar pada Syaikh Muhammad Yaqub, Syaikh Muhammad Ja'far, dan Syaikh Ali Hasan Ahmad al-Dari. ${ }^{21}$ Teman-temannya di Makkah antara lain Syaikh Ali Hasan Ahmad Pintu Padang Julu (Padangsidimpuan), Syaikh Abdul Wahab Muara Mais, Syaikh Ja'far Abdul Wahab (Padangsidimpuan), Syaikh Adnan Yahya (Medan), dan H. Miskuddin (Medan). ${ }^{22}$

\section{Nabundong, Sipirok, Tapanuli Selatan}

Kegiatan tarekat di Nabundong, Sipirok, Tapanuli Selatan dibina oleh Syaikh Ahmad Daud. Ia, yang nama kecilnya Binu Siregar dan lebih populer dengan sebutan Tuan Nabundong, lahir tahun 1891M di Sipirok Bagas Godang dan wafat 1981M di Nabundong. Pendidikannya diawali di Sipirok pada sekolah Vervolokh School (setingkat SD), kemudian tahun 1913M belajar di Basilam Langkat, tahun M berangkat ke Kedah Malaysia dan belajar di pesantren Air Hitam. Selanjutnya ia pergi ke Makkah untuk memperdalam ilmunya selama

${ }^{19}$ Sulaiman bin Syihabuddin, Mabâdi'u Mushthala $\underline{h}$ al- $\underline{H}$ adîts (Medan: Typ Indische Drukkerij, t.t).

${ }^{20}$ Anwar Saleh, "Sejarah Ulama," h. 49.

${ }^{21}$ Sulaiman, Mabadi'u, h. 4-5.

${ }^{22}$ Anwar Saleh, "Sejarah Ulama," h. 49 dan 51. 
7 (tujuh) tahun. Di antara gurunya adalah Syaikh Abdul Jalil al-Mandili dan Tuan Guru Mukhtar.

Kemudian, karena di Hijaz terjadi perang Wahaby, Ahmad Daud pulang ke tanah airnya. Sekitar tahun 1923M, ia mendirikan pondok pesantren di Desa Gunungtua Julu Sosopan. Karena tempat tersebut sempit dan tanah pertapakannya pinjam pakai, lalu ia memindahkan lokasi pesantrennya ke Aek Nabundong (kira-kira 3 km jaraknya dari Desa Gunungtua Julu) tahun 1925M, kemudian karena tempat tersebut dirasakannya juga kurang strategis, karena jauh dari pasar, ia pun memindahkan lagi pesantrennya ke Nabundong, dan ia namakan pesantren tersebut dengan Pesantren Darul Ulum Nabundong. Tahun 1952M, di samping mengelola pesantren, Syaikh Ahmad Daud juga membuka Persulukan tarekat Naqsyabandiyah yang diterima dari ayahnya, Syaikh Daud, dan ayahnya menerimanya dari Tuan Guru Basilam, Syaikh Abdul Wahab Rokan. Menurut keterangan anaknya kepada Anwar Saleh Daulay et.al., bahwa Syaikh Ahmad Daud pernah mengalami keadaan fana (tidak bergerak, tidak makan, dan tidak minum) selama 14 (empat belas) hari dalam kelambu suluknya. Kegiatan yang dibinanya kemudian dilanjutkan oleh putranya yang tertua, H. Daud Ahmad, alumni Candung Sumatera Barat, sedangkan putranya yang lain, H. Usman, alumni pesantren Cirebon, membuka pesantren sendiri di Aek Linta. ${ }^{23}$

\section{Pudun, Padangsidimpuan Batunadua, Padangsidimpuan}

Syaikh Zainal Abidin, bermarga Harahap, lahir di Pudun Padangsidimpuan ( $+1811-$ 1321H/1903). ${ }^{24}$ Nama lengkapnya Syaikh Zainal Abidin bin Sutan Maujalo bin Baginda Mauluddin. Pada makamnya di Pudun Julu Padangsidimpuan Batunadua tertulis dengan tulisan Arab-Jawi "Maulana Tuan Syaikh Zainal Abidin bin Sultan Maujalo Orang Kampung Pudun Julu, berpulang ke Rahmatullah 1321".

Syaikh Zainal Abidin Harahap, yang beristrikan seorang puteri Banten, Hajjah Habibah, belajar di Makkah selama 30 (tiga puluh) tahun, ${ }^{25}$ sejak usianya 19 (sembilan belas) tahun. Konon, Syaikh Zainal Abidin berteman baik dan bertemu Syaikh Abdul Wahab Rokan di

${ }^{23}$ Ibid., h. 75-81.

${ }^{24}$ Tahun lahir Syaikh Zainal Abidin didasarkan kepada informasi yang menyatakan bahwa beliau meninggal dalam usia sekitar 92 tahun. Lihat Armyn Hasibuan, "Tarekat Naqsyabandiyah Syekh Abdul Manan Siregar di Padangsidimpuan: Studi tentang Ajaran, Sosialisasi dan Kaderisasi", (Tesis : IAIN Sumatera Utara Medan, 2003), h. 38. Menurut perhitungan Armyn, ia lahir kirakira tahun 1809, dengan perhitungan: tahun meninggalnya dikurangi 92 tahun usianya, tetapi menurut perhitungan penulis, ia lahir kira-kira tahun 1811, dengan perhitungan tahun meninggalnya, 1321H dikonversi menjadi 1903 (1 Muharram 1321 Hijriah jatuh pada tanggal 30 Maret 1903 (lihat www.islamicfinder.org) dikurangi 92 tahun usianya, sehingga menjadi 1811.

${ }^{25}$ Burhan P. Liang, "Kisah di Balik Mesjid Tua, Tulila dari Tor Guba," dalam Analisa, (Minggu, 8 Mei 1977), h. 12 (informasi dari Junjungan Harahap, cucu Syeikh Zainal Abidin). 
Makkah, pada saat mengikuti suluk dengan Syaikh Sulaiman Zuhdi di Jabal Qubaisy sekitar tahun 1848. Syaikh Abdul Wahab Rokan belajar dan mengikuti suluk di Jabal Qubaisy selama 6 (enam) tahun, dan kembali ke Indonesia sekitar tahun 1854, sementara Syaikh Zainal Abidin diperkirakan belajar pada Syaikh Sulaiman Zuhdi antara tahun 18481853. ${ }^{26}$ Dikabarkan bahwa selama di Makkah ia juga pernah melakukan suluk di Gua Hira' selama 44 (empat puluh empat) hari. ${ }^{27}$

Ketika kembali ke tanah air, Syaikh Zainal Abidin langsung ke Banten dengan tujuan menambah ilmu pengetahuannya. Sejak tahun 1868 ia bermukim di Banten, kemudian, tahun 1874 ia kembali ke Pudun Julu. ${ }^{28}$ Ia, di samping mempunyai keahlian dalam bidang ilmu agama, juga mempunyai keahlian dalam pengobatan secara mistik (sufistik). Dalam bidang ini, ia dibantu oleh Nan Bakuro, yang juga ahli dalam pengobatan seperti ini.

Di Pudun Julu, kemudian, ia membangun sebuah masjid tahun 1901 (sesuai dengan tahun yang tertulis di pintu masuk mesjid). Di samping sebagai tempat ibadah, masjid ini juga dijadikan sebagai tempat melaksanakan kegiatan suluk. Sayangnya, 2 (dua) tahun kemudian, tahun 1321/1903, Syaikh Zainal Abidin meninggal dunia. Murid-muridnya, tidak hanya berasal dari daerah sekitar, tetapi juga berasal dari daerah lainnya, seperti Unte Rudang (Padang Lawas), Panyabungan, dan Pancur Pakko Sipirok. ${ }^{29}$

\section{Aek Tuhul, Padangsidimpuan Timur}

Kegiatan persulukan di Aek Tuhul, Padangsidimpuan Timur, dikembangkan oleh Syaikh H. Bosar Hasibuan, atau Abdul Halim Hasibuan, disebut juga Abu Muhammad Nur Halim Hasibuan, lahir di Paringgonan, Sibuhuan, Tapanuli Selatan tahun 1859, dan meninggal sekitar tahun 1931. Bosar Hasibuan Ia adalah salah seorang khalifah Syaik Zainal Abidin Pudun Julu. Tahun 1878, ia, yang usianya ketika itu 19 tahun, ikut melaksanakan ibadah haji bersama orangtuanya, dan ia tinggal menetap di Hijaz selama 7,5 tahun untuk belajar di Masjid al-Haram.

Kira-kira tahun 1886, ia kembali ke kampung halamannya di Sibuhuan, kemudian pindah ke Padangsidimpuan sekitar tahun 1888, dan menetap di Aek Tuhul Padangsidimpuan Timur. ${ }^{30}$ Sumber lain menyebutkan, bahwa Bosar pergi ke Makkah ketika berusia 12 (dua belas) tahun, menetap di Makkah selama 30 (tiga puluh) tahun, kembali ke tanah air tahun 1900, dan meninggal tahun $1920 .^{31}$

\footnotetext{
${ }^{26}$ Armyn, "Tarekat Naqsyabandiyah," h. 38-40

${ }^{27}$ Burhan P. Liang, "Kisah di Balik Mesjid Tua," h. 12.

${ }^{28}$ Armyn, "Tarekat Naqsyabandiyah," h. 38-40

${ }^{29}$ Burhan P. Liang, "Kisah di Balik Mesjid Tua," h. 12.

${ }^{30}$ Armyn, "Tarekat Naqsyabandiyah," h. 49, 51, 52.

${ }^{31}$ Harun Nasution, Ensiklopedi Islam, h. 178.
} 
Pada tahun 1901, ia membangun sebuah masjid, yang sebelumnya berupa surau (musala) yang dibangun setahun sebelumnya (1900), di lokasi Masjid Raya Lama Padangsidimpuan sekarang, dan mulailah diadakan shalat Jum'at di masjid tersebut. Sejak tahun 1907 sampai 1924, di masjid itu juga diadakan pengajian dan persulukan. Gurunya, Syaikh Zainal Abidin, sering juga memberi pengajian di masjid itu pada masanya. ${ }^{32}$

Di antara guru-gurunya di Makkah yaitu Syaikh Umar Hamdan, Syaikh Asy'ari Bawean, Syaikh Kendi, dan Syaikh Daud Fatani. Sedangkan murid-muridnya, antara lain Syaikh Kadir dari Aek Pining Batang Toru, Syaikh Abdurrahman dari Sialogo, Haji Daud dari Mompang Julu, dan Haji Abdul Halim Pardede di Prapat. ${ }^{33}$

\section{Ujung Padang, Padangsidimpuan Selatan}

Pengembangan tarekat Naqsyabandiyah di Ujung Padang, Padangsidimpuan dilakukan oleh seorang khalifah Syaikh Abdul Wahab Rokan (1811-1926), yaitu Syaikh Abdul Manan. Ia, yang lahir di Pagaran Dolok (Langsar) Sipirok, Tapanuli Selatan tahun 1884 dan meninggal tahun 1989, merupakan syaikh Naqsyabandiyah yang paling berpengaruh di wilayah tersebut pada masanya. ${ }^{34}$ Penyebutan nama Abdul Manan (Abd. Manan) di antara nama-nama khalifah Abdul Wahab Rokan, sebagaimana disebutkan oleh cucunya, Ahmad Fuad Said, berada pada nomor pertama dari 14 (empat belas) murid/khalifah Abdul Wahab Rokan yang berasal dari Tapanuli Selatan. Ini, tampaknya, menunjukkan bahwa Syaikh Abdul Manan merupakan murid/khalifah Khalidiyah Naqsyabandiyah "generasi pertama dan utama" dalam bimbingan Abdul Wahab Rokan. Khalifah lainnya adalah Muhammad Arsyad, Muhammad Nur, Kasim, Abd. Kadir, Mukmin, Sulaiman, Malim Itam, Muhammad Rasyid, Muhammad Saleh, Ahmad, Yakin, Sulaiman, dan Ramadhan. ${ }^{35}$

Syaikh Abdul Manan belajar pada Syaikh Abdul Wahab Rokan di Babussalam (Besilam), Langkat, Sumatera Utara, selama 12 (dua belas) tahun (1914-1926). Akhir tahun 1926, atau mungkin awal tahun 1927, Syeikh Abdul Manan kembali ke Tapanuli Selatan, dan tinggal di Padangsidimpuan (tidak kembali ke tempat kelahirannya, Langsar Sipirok). Pada tahun 1936 ia mendirikan sebuah pesantren yang dinamakan Pesantren Darus Salam, yang pada mulanya dikhususkan untuk qurra'u al-Qur'an (seni baca al-Qur'an). Santrinya, 45 (empat puluh lima) orang tinggal di pesantren tersebut, dan pulang ke rumah satu kali dalam 2 (dua) minggu atau satu bulan. Pesantren tersebut tidak bertahan lama, hanya kira-kira 4 (empat) tahun saja (1936-1940). Para santri banyak yang berhenti, sementara 13 (tiga belas) orang santrinya yang bertahan diizinkan untuk melanjutkan ke tempat lain. ${ }^{36}$

\footnotetext{
${ }^{32}$ Armyn, "Tarekat Naqsyabandiyah," h. 45, 55, 56.

${ }^{33}$ Harun Nasution, Ensiklopedi Islam, h. 178.

${ }^{34}$ Martin van Bruinessen, Tarekat Naqsyabandiyah, h. 143.

${ }^{35}$ Said, Syeikh Abdul Wahab, h. 135.

${ }^{36}$ Armyn, "Tarekat Naqsyabandiyah," h. 6, 88, 89, dan 127.
} 
Tahun 1941 Syaikh Abdul Manan mulai menggalakkan kegiatan tarekat dan persulukan, sebagaimana dipelajarinya dari Syaikh Abdul Wahab Rokan. Pesantren Darus Salam berubah menjadi tempat suluk. Pada bulan Zulhijjah tahun 1941 Masehi dimulai kegiatan suluk dengan muridnya 76 (tujuh puluh enam) orang. Masa kejayaan tarekat dan persulukan Syaikh Abdul Manan terjadi dalam periode 1943-1960. Dalam kurun waktu itu, ia telah membentuk pengajian-pengajian khusus tarekat di beberapa desa. Adapun desa-desa tersebut, antara lain Desa Aek Najaji, Siuhom, Simasom (Padangsidimpuan Timur), Borgottopong, Huta Lereng, Hutaimbaru (Padangsidimpuan Hutaimbaru), Langsar (Sipirok), Labu Layan (Padangsidimpuan Barat), Napa (Siais), Ujung Gurap, Ujung Padang (Padangsidimpuan Selatan), Pijor Koling (Padangsidimpuan Tenggara), dan Simanordang Batunadua (Padangsidimpuan Batunadua). ${ }^{37}$

\section{Batu Gajah, Barumun, Padang Lawas}

Tarekat Naqsyabandiyah di Batu Gajah, Barumun, Padang Lawas dikembangkan oleh Syaikh Muhamamd Thoib (1857-1964). Syaikh Muhammad Thoib, yang nama kecilnya Kamal Nasution dan lebih popular dipanggil Baleo Batugajah, lahir tahun 1857 di Kotanopan Rao Pasaman Sumatera Barat dan wafat pada tahun 1964 di Batugajah Barumun. Awalnya, ia belajar al-Qur'an di Kotanopan Rao Dolok pada H. Abdullah, kemudian ia belajar tarekat pada Syaikh Marif juga di Kotanopan Rao Dolok dan pada Syaikh Ibrahim al-Khalidi Kumpulan, Sumatera Barat. Akhirnya ia pergi belajar ke Mekkah di Jabal Qubis pada Syaikh Sulaiman Zuhdi dan Syeikh Musa. ${ }^{38}$

Ketika kembali ke tanah air, ia membuka sebuah lembaga pendidikan Islam di Hutalombang Kotanopan Rao dengan murid pertamanya mencapai 700 orang yang diajarinya ilmu akidah, akhlak, dan tasawuf. Kemudian atas permintaan Raja Hapung Sosa Tapanuli Selatan ia pindah ke Hapung, Sosa, sekitar tahun 1925. Di tempat baru ini ia mengembangkan Islam melalui suluk/tarekat dan pengajian al-Qur'an selama 7 (tujuh) tahun. Masjid pun dibangun, sebelumnya belum ada. Kebiasaan buruk masyarakat, seperti berjudi, mabuk, dan suka berkelahi berangsur-angsur mereka tinggalkan.

Tahun 1931 ia pindah ke Batugajah, Barumun, dan juga membuka suluk/tarekat dan pengajian al-Qur'an yang murid-muridnya mencapai 500 orang, sehingga ia terkenal dengan sebutan Baleo Batugajah. Tradisi suluk/tarekat ini kemudian diteruskan oleh anaknya, Syaikh Musa Nasution (w. 1982), alumni Madrasah Basilam Langkat, selanjutnya diteruskan oleh anaknya yang kedua, Syaikh Imam Kari Nasution. ${ }^{39}$

${ }^{37}$ Ibid., h. 81, 90, dan 91. Keterangan dari Syeikh H. Muhammad Yaqub Siregar, 2001 [khalifah, penerus, dan anak Syeikh Abdul Manan], dan Ahmad Hasan, 2002 [khalifah Syeikh Abdul Manan].

${ }^{38}$ Anwar Saleh, "Sejarah Ulama," h. 82.

${ }^{39}$ Ibid., h. 82, 83, dan 85. 


\section{Penutup}

Penyebaran tarekat Naqsyabandiyah di Tapanuli Bagian Selatan hampir langsung mengikuti para juru dakwah Islam pertama, yang pengaruhnya datang dari dua sumber, yaitu dari Minangkabau, khususnya melalui Syaikh Ibrahim Kumpulan; dan dari Babussalam, Langkat, dengan figur utama Syaikh Abdul Wahab Rokan. Meskipun demikian, sebagian syaikh Naqsyabandiyah asal Tapanuli Bagian Selatan, setelah belajar pada syeikh setempat, pergi ke Makkah, dan belajar langsung pada Syaikh Sulaiman Zuhdi atau Ali Ridha di Jabal Abu Qubaisy, atau ulama lainnya.

Tarekat Naqsyabandiyah berkembang di beberapa tempat di wilayah Tapanuli Bagian Selatan. Organisasi tarekat tertentu biasanya terpusat secara terus-menerus di suatu tempat hingga beberapa generasi, namun sebagiannya tidak bertahan karena faktorfaktor tertentu. Di antara pusat-pusat perkembangan tarekat Naqsyabandiyah di Tapanuli Bagian Selatan adalah Hutapungkut, Kota Nopan, Mandailing Natal; Aek Libung, Sayurmatinggi, Tapanuli Selatan; Nabundong, Sipirok, Tapanuli Selatan; Pudun, Padangsidimpuan Batunadua, Padangsidimpuan; Aek Tuhul, Padangsidimpuan Selatan, Padangsidimpuan; Ujung Padang, Padangsidimpuan Timur, Padangsidimpuan; dan Batu Gajah, Barumun, Padang Lawas.

\section{Pustaka Acuan}

Abdullah, Taufik. Sejarah Lokal di Indonesia. Yogyakarta: Gajah Mada University Press, 1979.

Azra, Azyumardi. Renaisans Islam Asia Tenggara: Sejarah Wacana \& Kekuasaan. Jakarta: Remaja Rosdakarya, 2006.

Azra, Azyumardi. Jaringan Ulama Timur Tengah dan Kepulauan Nusantara Abad XVII dan XVIII: Akar Pembaruan Islam Indonesia. Jakarta: Kencana, 2004.

Bruinessen, Martin van. Tarekat Naqsyabandiyah di Indonesia. Cet. 4, Bandung: Mizan, 1996.

Daulay, Anwar Saleh, et.al. "Sejarah Ulama Ulama Terkemuka Tapanuli Selatan." Penelitian: Fakultas Tarbiyah IAIN Sumatera Utara, Padangsidimpuan, 1987.

Hasibuan, Armyn. "Tarekat Naqsyabandiyah Syekh Abdul Manan Siregar di Padangsidimpuan (Studi tentang Ajaran, Sosialisasi dan Kaderisasi)." Tesis : IAIN Sumatera Utara Medan, 2003.

Hasyim, Arrazy. "Al-Tariqah al-Naqsyabandiyah fi Minangkabau: Tarjmat Kitab al-Sa'adah al-Abadiyah li Shaykh 'Abd al-Qadim”, dalam Studia Islamika, Volume 18, Nomor $1,2011$.

Liang, Burhan P. "Kisah di Balik Mesjid Tua, Tulila dari Tor Guba", dalam Analisa, Minggu, 8 Mei 1977.

Nasution, Harun et.al. Ensiklopedi Islam Indonesia. Jakarta: Djambatan, 1992. 
MIQOT Vol. XXXVIII No. 1 Januari-Juni 2014

Nur, Djamaan. Tasawuf dan Tarekat Naqsyabandiyah Pimpinan Prof. Dr. H. Saidi Syeikh Kadirun Yahya. Cet. 2. Medan: USU Press, 2002.

Said, A. Fuad. Syeikh Abdul Wahab Tuan Guru Babussalam. Medan: Pustaka Babussalam, 1983.

Syihabuddin. Adab al-Muridin. Medan: Pertjatimoer, t.t.

Syihabuddin. Fath al-Qalb. t.t.p: t.p., t.t.

Sulaiman bin Syihabuddin. Mabadiu Mushthalah al-Hadits. Medan: Typ Indische Drukkerij, t.t.

Pelly, Usman. "Ulama di Mandailing, sebagai Bahan Perbandingan untuk Kasus Kaji: Ulama di Tiga Kerajaan Melayu Pesisir." Bulletin Proyek Penelitian Agama dan Perubahan Sosial (LEKNAS-LIPI), No. 6. 